\section{Human parvovirus aplasia: case due to cross infection in a ward}

Infection with human parvovirus is an important cause of aplastic crises in patients with sickle cell anaemia. ${ }^{1}$ Recently the virus has been implicated in aplastic crises in hereditary spherocytosis ${ }^{2}$ and pyruvate kinase deficiency. ${ }^{3}$ Epidemiological studies suggest that the virus causes an illness with an incubation period of about nine days, ${ }^{4}$ resulting in suppression of erythropoiesis for five to 10 days.

We report two cases of human parvovirus aplasia presenting in North London in which the infection was probably transmitted within a hospital ward and examine the implications of this finding.

\section{Case reports}

Case 1-A 4 year old girl was admitted on 9 July 1983 with a history of headache, vomiting, and fever for 24 hours. She suffered from hereditary spherocytosis and her haemoglobin concentration had been stable at around $10.5 \mathrm{~g} / \mathrm{dl}$. On examination she was seen to be pale and her spleen was palpable $3 \mathrm{~cm}$ below the left costal margin. Haemoglobin concentration was $7.8 \mathrm{~g} / \mathrm{dl}$, white cell count $7.9 \times 10^{\circ} / \mathrm{l}$, and reticulocyte count $8 \%$. After a blood transfusion her symptoms disappeared. She was discharged two days later with a haemoglobin concentration of $10.0 \mathrm{~g} / \mathrm{dl}$ and a reticulocyte count of $0 \cdot 2 \%$. On 20 July she was readmitted; she did not have symptoms but her haemoglobin concentration was $6.8 \mathrm{~g} / \mathrm{dl}$ and reticulocyte count $4.5 \%$ and she was given a second transfusion. Serum tests 12 days after presentation confirmed recent infection with human parvovirus: antihuman parvovirus IgM 56 radioimmunoassay units, antihuman parvovirus IgG 40 units. She subsequently required no more blood.

Case 2-A 12 year old girl with homozygous sickle cell anaemia was admitted on 8 July 1983 with an infarctive sickle crisis. On admission she had a haemoglobin concentration of $9.4 \mathrm{~g} / \mathrm{dl}$ and a reticulocytosis of $8 \%$. She was treated with fluids, antibiotics, and analgesics and discharged with a haemoglobin concentration of $8.9 \mathrm{~g} / \mathrm{dl}$ and a reticulocytosis of $12.6 \%$. On 20 July she began to have headache and fever and seven days later she was readmitted. Haemoglobin concentration was $3.3 \mathrm{~g} / \mathrm{dl}$, white cell count $10.9 \times 10^{9} / 1$, and platelet count $340 \times 10^{9} / 1$. She had complete reticulocytopenia. Her clinical condition improved after blood transfusion and she was discharged after four days, when reticulocytes were again detectable. Serum assays during the first admission showed no evidence of current or previous infection with human parvovirus. During her second admission high levels of human parvovirus specific IgM antibody were detected, indicating recent infection (table).

Haematological and virological data in case 2. (Contact with case 1 during 9-11 fuly 1983)

\begin{tabular}{|c|c|c|c|c|c|}
\hline & & \multicolumn{4}{|c|}{ Date } \\
\hline & & $8 / 7 / 83$ & $13 / 7 / 83$ & $27 / 7 / 83$ & $10 / 8 / 83$ \\
\hline $\begin{array}{l}\text { Haemoglobin concentration (g/dl) } \\
\text { Reticulocytes (\%) } \\
\text { Antihuman parvovirus } \\
\text { (radioimmunuassay units) }\end{array}$ & $\left\{\begin{array}{l}\mathrm{IgM} \\
\mathrm{IgG}\end{array}\right.$ & $\begin{array}{r}9 \cdot 4 \\
8 \cdot 0 \\
<1 \cdot 0 \\
<0.3\end{array}$ & $\begin{array}{r}8 \cdot 7 \\
12 \cdot 0 \\
<1 \cdot 0 \\
<0 \cdot 3\end{array}$ & $\begin{array}{r}3 \cdot 3 \\
0 \\
>100 \cdot 0 \\
12 \cdot 5\end{array}$ & $\begin{array}{r}9 \cdot 8 \\
2 \cdot 4 \\
>100 \cdot 0 \\
64 \cdot 0\end{array}$ \\
\hline
\end{tabular}

\section{Comment}

Our interest in these two cases lies in the possibility of cross infection with human parvovirus in a hospital ward. The patient with hereditary spherocytosis was admitted with a feverish illness. She subsequently developed a low reticulocyte count and required transfusion on two occasions for the first time in her life. The patient with sickle cell anaemia was in hospital with an infarctive crisis when she was exposed to the patient with hereditary spherocytosis. She developed new symptoms between nine and 11 days after contact and was admitted one week later severely anaemic and with absent reticulocytes. The spread of aplastic crisis among patients with haemolytic anaemia in hospital has not been noted before, but the timing of contact and subsequent clinical course in our patients strongly suggest that the second was infected with human parvovirus by the first and developed an aplastic crisis as a result.

The epidemic nature of aplastic crisis in sickle cell anaemia is well recognised ${ }^{\mathbf{l}}$ and outbreaks in families with hereditary spherocytosis have been repeatedly reported. Human parvovirus appears to be the predominant cause. ${ }^{4}$

Infection with human parvovirus is prevalent wherever it has been looked for. Some $30-40 \%$ of blood donors in Britain and Australia have antibody against the virus. ${ }^{2}$ In normal people infection with the virus may be subclinical or may cause a mild feverish illness with vomiting, hypochondrial pain, and myalgia. It also appears to be the cause of erythema infectiosum (fifth disease), ${ }^{5}$ an acute exanthematous disease of children. Most infections are mild, but in patients whose red cells have an appreciably reduced life span erythroid suppression due to the virus results in a rapid and life threatening fall in haemoglobin concentration, as seen in our second patient.

Once an aplastic crisis is established management is supportive. It may, however, be possible to prevent aplastic crises with normal human immunoglobulin which has a high titre of antibody against human parvovirus. Its use should be considered in family and hospital contacts of human parvovirus infection who have haemolytic anaemia as soon as the risk is recognised.

This is the first report of probable spread of the disease in hospital and it emphasises the danger of contac.s between patients with possible parvovirus infection and known cases of haemolytic anaemia. In the management of haemolytic anaemias the threat of infection with human parvovirus, the potential protective effect of passive antibody, and the availability of specific tests for susceptibility and for current infection are all important considerations.

${ }^{1}$ Sergeant GR, Topley JM, Mason K, et al. Outbreak of aplastic crises in sickle cell anaemia associated with parvovirus-like agent. Lancet 1981 ;ii: 595.

2 Kelleher MD, Naomi LC, Luban MD, Mortimer PP, Kamimura T. Human serum "parvovirus." A specific cause of aplastic crises in children with hereditary spherocytosis. I Pediatr 1983;103:720-2.

${ }^{3}$ Duncan JR, Potter CG, Cappelini MD, Kurtz JB, Anderson RJ, Weatherall DJ. Aplastic crisis due to parvovirus infection in pyruvate kinase deficiency. Lancet 1983 ;ii:14-6.

4 Mortimer PP. Hypothesis: the aplastic crisis of hereditary spherocytosis is due to a single transmissible agent. F Clin Pathol 1983;36:445-8.

${ }^{5}$ Anderson MJ, Jones SE, Fisher-Hoch SP. Human parvovirus, the cause of erythema infectiosum (fifth disease) ? Lancet 1983;i:1378.

(Accepted 25 November 1983)

North Middlesex Hospital, Edmonton, London N18 1QX

JANE P M EVANS, MA, MRCP, senior registrar in haematology MARY A ROSSITER, MRCP, DCH, consultant paediatrician T O KUMARAN, MRCP, MRCPATH, consultant haematologist G W MARSH, MD, FRCPATH, consultant haematologist

PHLS Virus Reference Laboratory, Central Public Health Laboratory, London NW9 5HT

P P MORTIMER, MD, MRCPATH, consultant microbiologist

Correspondence to: Dr Jane P M Evans.

\section{Unusual dislocations associated with epileptic fits}

Dislocation of a joint is a possible complication of epileptic fits. I report two cases of unusual joint dislocations resulting from epileptic fits that do not appear to have been described previously.

\section{Case reports}

Case 1-A 32 year old housewife with a history of three epileptic fits since childhood was noted by her husband to be walking around in a daze and not responding to questions. He then observed her sit down and start twitching in her arms and legs; her eyes rolled up, and she frothed at the mouth. She repeatedly flung her arms across her chest and finally upwards into the air, at which stage she became unrousable. On arrival at the accident and emergency department she was conscious but drowsy and disorientated. There was no evidence of incontinence, tongue biting, or other neurological signs. Further examination showed a deformity of both shoulders, which proved on $x$ ray examination to be bilateral anterior dislocation of the shoulder joints plus a fractured right greater tuberosity. An electroencephalogram obtained at a later date was consistent with epilepsy. The dislocations were reduced easily under sedation with intravenous diazepam, and the arms were rested in 